\title{
EDITORIAL
}

\section{Max Coates}

As we are compiling this first edition of the Buckingham Education Journal, the UK is in lockdown. To say that we are living in challenging times would be a gross understatement. People - our family, neighbours, friends and colleagues - are trying to avoid contracting COVID-19 by social distancing and by self-isolating. The ordinary has become the extraordinary as we have to plan to obtain food, medication, take exercise and remain in contact. As schools have closed, potentially an extended period, the education of children at home has become a fascinating area. School staff are doing amazing work in preparing materials for enforced home schooling and preparing in school materials for the children of key workers. However, conversations with school leaders (by Skype!) are reporting that there is a divide, with many parents stepping up to the mark and being inventive whilst other parents are maintaining an eerie silence. Bearing in mind that this period of lockdown represents around $4 \%$ of children's compulsory schooling, will we see a divide in educational achievement linked to these different levels of parental engagement?

Thinking beyond the limitations imposed by containing the virus, it seems unlikely that the world will simply reset and that this whole situation will eventually seem like a pernicious sequel to Back to the Future. It is likely that the way that we work will change and 'working from home' will be increasingly the norm and not a euphemism for a day off! The way that we engage with the medical services will become routinely virtual. There will be a downscaling of business premises as many staff work remotely. Probably, international travel will reduce. Formal education will become increasingly dominated by the use of technology, with the teacher taking the role of facilitator rather than being didactic. In turn, this could well challenge perceptions of the structure of knowledge and what is essential and what might be considered peripheral as children routinely become 'free range in their use of online resources. It is likely that our reality will become parochial and our virtual engagement global. Of course, many of these possibilities have been trending for some time. The pandemic has and will accelerate this trend. What will this mean for our education system? We will almost certainly not return to the 2019 educational time capsule, and the debate around the curriculum must surely intensify.

This inaugural edition joins this debate about schooling and its function and intention. It has a significant focus on the challenges of creating a curriculum which is contemporary, relevant and future-proofed, and which contributes to 


\section{EDITORIAL}

areas such as equity, employability and well-being. Amongst our contributors, Mark Deacon begins to address the problem of how the rapid and extensive growth in scientific knowledge can be accommodated within the confines of finite allocation within schools. Barnaby Lenon engages with the nature and appropriateness of the secondary-school curriculum. Max Coates provides a helicopter view of the development of the English curriculum and proposes/ exposes some of the ideological assumptions that have driven its evolution. Simon Edwards looks at pupil absenteeism as an indicator of pupil engagement with schools rather than as an issue to be administered.

Overall, the articles represent an eclectic mix of thinkers and their thinking on education. The span of the articles was never intended to be totally coherent. However, I believe that you will find them thought-provoking and even controversial. They will certainly enliven the long overdue debate about the redesign of the UK curriculum, but they also have traction within the international education community. Perhaps it is a case of changing times, changing curriculum.

In many ways, The University of Buckingham is a relatively 'new kid on the block', becoming a university college in 1973 and gaining its university status by royal charter in 1983. It is a private university, so it lacks the government funding which is the bedrock of most other UK universities. It does, however, comply with full academic requirements of higher education in this country. It is not the local Spar shop set against Tesco, like comparing it with larger players like University College London. It is known for having a radical edge, many will have heard of it as the home of the two-year degree, using four-term years to prune time but not quality from its degree programmes. There is a resonance with innovation and fresh thinking is at its core. This journal is a further manifestation of this, as we seek to showcase ideas and concepts and not simply become an organ of academic activity.

It has been a privilege to be the editor of this first edition; however, I am fronting a formidable team. I would particularly like to thank our Vice Chancellor, Sir Anthony Seldon, and the Dean of Education, Professor Barnaby Lenon CBE, for their unstinting support and encouragement for this project. Of course, thanks are due to the contributors who have so willingly written for the journal and shared their thinking. Mark Deacon, who moved seamlessly from being a contributor to becoming an honorary subeditor, many thanks for all your support and advice. Especial thanks are due to Jonathan Reuvid MA, Editor in Chief, University of Buckingham Press (very much my mentor), and at Legend Press; Christian Müller for his detailed editorial skills; and of course Tom Chalmers the Publisher of UBP and managing director of the Legend Times Group. 